\title{
Tourist's Perception On The "Touch Samosir" Application As Tourism Information Service In Samosir Island, Lake Toba, North Sumatera
}

\author{
Dewi Yanti ${ }^{1}$ \\ Medan Tourism Polytechnic \\ Medan, Indonesia \\ dewie.yanthi@gmail.com
}

\author{
Yon Suprapto ${ }^{2}$ \\ Medan Tourism Polytechnic \\ Medan, Indonesia \\ yonsaham@gmail.com
}

\author{
Asmah Kartika ${ }^{3}$ \\ Medan Tourism Polytechnic \\ Medan, Indonesia \\ asmakartika@yahoo.com
}

\begin{abstract}
The Touch Samosir application is an androidbased mobile phone application that serves to help users, namely tourists in obtaining a variety of information, ranging from tourist attractions, hotels, restaurants, transportation, culinary, attractions, to souvenirs in Samosir Regency around Lake Toba which is the largest lake in Asia which has a lot of tourism potential and is an icon of national tourism after Bali. This research aims to determine the extent to which users utilize the Samosir Tourism Promotion Application "Touch Samosir" as a tourism information service in Samosir district that helps tourists get actual information about tourist attractions in the area. The method used in this study is descriptive because this study analyzes and presents facts systematically so that it can be more easily concluded. Data collection was carried out by distributing questionnaires and observations.

The results showed that the majority of users $(62 \%)$ had taken advantage of samosir touch applications by spending less than 1 hour every time they searched information. In general, respondents $(\mathbf{7 5 \%})$ know the existence of samosir touch applications through print / electronic media. Users most often use content from facilities features that exist in the Samosir touch application. It shows that information facilities are the most sought after by users because they contain information such as hotels, homestays, souvenirs, restaurants, taxis \& rentals and so on that help users during their tour in Samosir.
\end{abstract}

Keywords- Application, Application Utilization, Touch Samosir

\section{INTRODUCTION}

The development of tourism in Indonesia has experienced a significant increase. This increase is seen from the number of foreign tourists visiting Indonesia increasing from year to year. The tourism sector in Indonesia has become one of the government's priority programs that must be improved because tourism will have a significant impact on the economy. This is because tourism has a very important role in the development of Indonesia, especially as a foreign exchange earner in addition to the oil and gas sector.

The Government through the Ministry of Tourism in 2016 determined 10 priority destinations that would become the focus of tourism development in Indonesia which is expected to accommodate millions of tourists. The tourist destinations include Lake Toba. Samosir Regency is one of the districts that surround Lake Toba. Very many tourism objects in Samosir Regency, not only talk about nature and culture, various historical relics can also be found in Samosir Regency. At present Samosir Regency Tourism Office has provided tourism information services not only through brochures, leaflets and the web. Even Samosir Regency Tourism Office has provided Samosir tourism promotion application called Touch Samosir which is an Android-based mobile phone application that can be downloaded for free.

One function of information technology for the tourism sector is as a medium of advertising and promotion. Information packaging in information technology is very necessary because it is one of the efforts to accelerate the delivery of information. Information packaging activities start from selecting information that comes from various sources, followed by data collection, analysis, and presentation in packaging that suits the needs of users. Information packaging will make it easier for users to get the right, complete and appropriate information and can be easily applied.

The Touch Samosir application is expected to help users, namely tourists in obtaining various information, ranging from tourist attractions, hotels, restaurants, transportation, culinary, attractions, to souvenirs. This application has just been launched in March 2016. This makes the author want to know whether the Samosir touch application is really used to help tourists in obtaining tourism information in Samosir Regency. To find out about this, the author conducted a study entitled "Tourist Perception of Samosir Tourism Promotion Application" Touch Samosir "as a Tourism Information Service in Samosir Regency. The body of the paper can be divided into three basic elements, which are introduction, main content, and conclusion. The introductory sectionstrategically presents the context, significance, focus, and organization of the paper. If necessary, notes of methodological issues can be made in a separate section.

\section{RESEARCH METHOD}

The research method is the scientific method used for research. The method used in this research is Descriptive. According to Azwan (2004: 7) "Descriptive research is to 
do analysis only to the stage of description, which is analyzing and presenting facts that can be more easily concluded".

Population is a complete group of elements, which usually consist of people, objects, transactions, or events where we are interested in learning it or being the object of research (Kuncoro, 2003: 103). The population in this study were users of the Samosir Touch application. The sample is part or representative of the total population. According to Arikunto (2002: 109) "The sample is part or representative of the population under study". There are several ways used to determine the sample. Determination of the sample of this study was carried out by purposive sampling technique. The definition of purposive sampling in the opinion of Arikunto (2002: 117) is the method of taking subjects not evenly over strata, random or regions, but carried out on the target of certain objectives. The purpose of sample selection is when the user touches the samosir who has opened the application. Data writing techniques in this study were carried out using the following techniques:

a. Observation (observation) is data that is used systematically and intentionally, which is done through observation and recording the facts investigated.

b. The questionnaire is collecting data by giving a list of questions (questionnaires) to be filled in by the respondent. To make it easier for users to make a list of questions as follows:

TABLE 1. QUESTIONNAIRE INDICATORS

\begin{tabular}{|c|c|c|c|}
\hline Variable & Indicator & $\begin{array}{l}\text { No. } \\
\text { Item }\end{array}$ & $\begin{array}{l}\text { Total } \\
\text { Item }\end{array}$ \\
\hline \multirow{8}{*}{$\begin{array}{c}\text { Samosir } \\
\text { Tourism } \\
\text { Promotion } \\
\text { Application } \\
\text { "Touch } \\
\text { Samosir" as } \\
\text { Tourism } \\
\text { Information } \\
\text { Service in } \\
\text { Samosir District }\end{array}$} & $\begin{array}{l}\text { 1. Application Service } \\
\text { Conditions }\end{array}$ & 1 & 1 \\
\hline & 2. Utilization Frequency & 2 & 1 \\
\hline & $\begin{array}{l}\text { 3. Introduction to } \\
\text { Applications }\end{array}$ & 3 & 1 \\
\hline & 4. Information Search & 4,6 & 3 \\
\hline & $\begin{array}{l}\text { 5. Application Utilization } \\
\text { Patterns }\end{array}$ & 5,8 & 2 \\
\hline & $\begin{array}{l}\text { 6. Electronic Information } \\
\text { Sources }\end{array}$ & 9 & 1 \\
\hline & $\begin{array}{l}\text { 7. Accuracy and } \\
\text { completeness of the } \\
\text { Application }\end{array}$ & $\begin{array}{l}10, \\
11\end{array}$ & 2 \\
\hline & 8. Application Content & $\begin{array}{l}12, \\
13\end{array}$ & 2 \\
\hline \multicolumn{3}{|c|}{ Total } & 13 \\
\hline
\end{tabular}

\section{Data analysis}

The data that has been collected is then analyzed. Data analysis was performed using descriptive statistics. According Sugiyono (2006: 21) "Descriptive statistics are statistics that can be used to describe or provide insight into the object under study through sample data or population, without using analysis and making conclusions that apply to the public". Data will be tabulated in accordance with the aspects studied, to facilitate interpretation of the data to be presented in table form and then analyzed and interpreted. In destroying the data, the author uses Supardi's interpretation method (1979: 20) using:
a. $1-24 \%$ : a small portion
b. $25-49 \%$ : almost half
c. $50 \%$ : half
d. $51-74 \%$ : most
e. $75-99 \%$ : for most
f. $100 \%$ : entirely

\section{RESEARCH RESULTS}

The results of the study and discussion on which data were obtained from questionnaires to research respondents in the Touch Samosir Application as Tourism Information Services in Samosir Regency. The number of samples taken in this study was 100 respondents.

Descriptive analysis in this study was measured based on application service condition indicators, application utilization frequency, application recognition, information tracking, application utilization patterns, electronic information sources, accuracy and completeness of applications, and application content.

\section{Conditions of the Samosir Touch Application Service}

The respondent's response to the use of tourism information service conditions on the Samosir touch application can be seen in table 2 below:

TABLE 2. APPLICATION SERVICE CONDITIONS

\begin{tabular}{|c|c|c|c|c|c|}
\hline & & Frequency & Percent & $\begin{array}{c}\text { Valid } \\
\text { Percent }\end{array}$ & $\begin{array}{c}\text { Cumulative } \\
\text { Percent }\end{array}$ \\
\hline \multirow[t]{5}{*}{ Valid } & Very Good & 21 & 21.0 & 21.0 & 21.0 \\
\hline & Good & 34 & 34.0 & 34.0 & 55.0 \\
\hline & Enough & 28 & 28.0 & 28.0 & 83.0 \\
\hline & $\mathrm{Bad}$ & 17 & 17.0 & 17.0 & 100.0 \\
\hline & Total & 100 & 100.0 & 100.0 & \\
\hline
\end{tabular}

From table 2 it can be seen that out of 100 respondents, 21 respondents $(21 \%)$ stated that the Samosir touch application service process was very good. Then 34 respondents (34\%) stated that the condition of Samosir's touch application service was good. Furthermore, 28 respondents $(28 \%)$ stated that the condition of samosir touch application service was not good, and 17 respondents (17\%) stated that samosir touch service was not good.

Based on the data above it can be concluded that almost half of the respondents stated that the Samosir touch service is good, not only using the web but the application can be downloaded in the Android system PlayStore. The use of bright colors, samosir area images, symbols on the menu makes the application touch samosir good and users easily understand it there is a photo in the header whose resolution does not match the image they look enlarged. 


\section{Frequency of Utilization of the Samosir Touch} Application

The respondent's response to the time used when accessing the Samosir touch application can be seen in table 3 below:

TABLE 3. FREQUENCY OF APPLICATION UTILIZATION

\begin{tabular}{|c|c|c|c|c|c|}
\hline & & Frequency & Percent & $\begin{array}{c}\text { Valid } \\
\text { Percent }\end{array}$ & $\begin{array}{l}\text { Cumulativ } \\
\text { e Percent }\end{array}$ \\
\hline \multirow{5}{*}{ Valid } & More than $3 \mathrm{hrs}$ & 3 & 3.0 & 3.0 & 3.0 \\
\hline & $2-3 \mathrm{hrs}$ & 12 & 12.0 & 12.0 & 15.0 \\
\hline & $1-2 \mathrm{hrs}$ & 23 & 23.0 & 23.0 & 38.0 \\
\hline & Less than $1 \mathrm{hr}$ & 62 & 62.0 & 62.0 & 100.0 \\
\hline & Total & 100 & 100.0 & 100.0 & \\
\hline
\end{tabular}

From table 3 it can be seen that out of 100 respondents, 3 respondents $(3 \%)$ stated that the time to access the samosir touch application is more than 3 hours. Then 12 respondents (12\%) stated that the time to access the touch application is 2-3 hours. Furthermore, 23 respondents $(23 \%)$ stated that the time to access the Samosir touch application was 1-2 hours, and 62 respondents $(62 \%)$ stated that the time in accessing the Samosir touching application was less than 1 hour.

Based on the data above it can be concluded that the majority of respondents regarding the time in accessing the Samosir Touch application is less than 1 hour. This time to use the search of events, destinations, facilities available on the Samosir touch application such as hotels and others that are used to help users in traveling.

\section{Samosir Touch Application Introduction}

To find out where the respondent initially knew the samosir touch application seen in table 4 below:

TABLE 4. INTRODUCTION TO APPLICATIONS

\begin{tabular}{|r|r|r|r|r|}
\hline Valid & $\begin{array}{c}\text { Freque } \\
\text { ncy }\end{array}$ & Percent & $\begin{array}{c}\text { Valid } \\
\text { Percent }\end{array}$ & $\begin{array}{r}\text { Cumulativ } \\
\text { e Percent }\end{array}$ \\
\hline $\begin{array}{c}\text { printed/electro } \\
\text { nic media }\end{array}$ & 75 & 75.0 & 75.0 & 75.0 \\
Social Media & 11 & 11.0 & 11.0 & 86.0 \\
Family/friends & 14 & 14.0 & 14.0 & 100.0 \\
Total & 100 & 100.0 & 100.0 & \\
\hline
\end{tabular}

From table 4 it can be seen that out of 100 respondents, 75 respondents $(75 \%)$ stated that they began to know samosir touch applications through print / electronic media. Then 11 respondents $(11 \%)$ stated that they began to know the touch application through social media. Furthermore, 14 respondents (14\%) stated that they started to know Samosir touch applications through friends / relatives.

Based on the data above it can be concluded that in general respondents began to know samosir touch applications through print / electronic media where the samosir local government, especially the Tourism and Culture Department, tried to introduce this samosir touch application as a tourism information service that aims to facilitate tourists through print media such as newspapers. and electronic media such as news websites.

\section{Samosir Touch Application Information Search a. Samosir Touch Application Menu}

The respondent's response to the menu available on the Samosir touch application is sufficient to be used in information retrieval can be seen in the following table 5:

TABLE 5. APPLICATION MENU

\begin{tabular}{|r|r|r|r|r|}
\hline & Frequency & Percent & $\begin{array}{c}\text { Valid } \\
\text { Percent }\end{array}$ & $\begin{array}{c}\text { Cumulative } \\
\text { Percent }\end{array}$ \\
\hline Valid $\quad$ Very adequate & 28 & 28.0 & 28.0 & 28.0 \\
& 32 & 32.0 & 32.0 & 60.0 \\
adequate & 26 & 26.0 & 26.0 & 86.0 \\
Less adequate & 14 & 14.0 & 14.0 & 100.0 \\
Not adequate & 100 & 100.0 & 100.0 & \\
Total & & & \\
\hline
\end{tabular}

From table 5 it can be seen that out of 100 respondents, 28 respondents $(28 \%)$ stated that the menus available on the Samosir touch application are very adequate to be used in information retrieval. Then 32 respondents (32\%) said that the menus available on the Samosir touch application were sufficient to be used in information retrieval. Furthermore, 23 respondents $(23 \%)$ said that the menus available in the Samosir Touch application were inadequate to be used in information retrieval, and 14 respondents (14\%) stated that the menus available on the Samosir Touch application were not sufficient to be used in information retrieval.

Based on the data above, it can be concluded that almost half of the respondents stated that the menus available on the Samosir touch application to be used in information retrieval are adequate because users feel that they have obtained information from the menu, especially menu facilities, even though the spa or massage category is not included in the menu. which is one of the needs in traveling.

\section{b. Samosir Touch Application Needs}

The respondent's response to the Samosir touch application can present any information needed can be seen in table 6 below: 
TABLE 6. APPLICATION REQUIREMENTS

\begin{tabular}{|rc|r|r|r|r|}
\hline & & Frequency & Percent & $\begin{array}{c}\text { Valid } \\
\text { Percent }\end{array}$ & $\begin{array}{c}\text { Cumulative } \\
\text { Percent }\end{array}$ \\
\hline Valid & Always & 21 & 21.0 & 21.0 & 21.0 \\
& Often & 28 & 28.0 & 28.0 & 49.0 \\
& Sometimes & 42 & 42.0 & 42.0 & 91.0 \\
& Never & 9 & 9.0 & 9.0 & 100.0 \\
& Total & 100 & 100.0 & 100.0 & \\
\hline
\end{tabular}

Source: Processed research data, 2017

From table 6 it can be seen that out of 100 respondents, 21 respondents $(21 \%)$ stated that the Samosir touch application can always present any information needed. Then 28 respondents (28\%) stated that the Samosir touch application often presents whatever information is needed. Furthermore 42 respondents (42\%) stated that the Samosir Touch application can sometimes present any information needed, and 9 respondents $(9 \%)$ stated that the Samosir Touch application never presents any information needed.

Based on the data above, it can be concluded that almost half of the respondents said that Samosir touch application can present any information needed only sometimes because there are still categories in the menu whose contents are not complete, such as promos, even though the user wants to find and get the information.

\section{The difficulty of the Samosir Touch Application}

The response rsponden to difficulties in accessing information provided by the Samosir touch application can be seen in the following table 7 :

TABLE 7. INFORMATION ACCESS DIFFICULTIES

\begin{tabular}{|c|c|c|c|c|c|}
\hline & & Frequency & Percent & $\begin{array}{c}\text { Valid } \\
\text { Percent }\end{array}$ & $\begin{array}{c}\text { Cumulative } \\
\text { Percent }\end{array}$ \\
\hline \multirow[t]{5}{*}{ Valid } & Always & 12 & 12.0 & 12.0 & 12.0 \\
\hline & Often & 16 & 16.0 & 16.0 & 28.0 \\
\hline & Sometimes & 39 & 39.0 & 39.0 & 67.0 \\
\hline & Never & 33 & 33.0 & 33.0 & 100.0 \\
\hline & Total & 100 & 100.0 & 100.0 & \\
\hline
\end{tabular}

From table 7 it can be seen that out of 100 respondents, 12 respondents (12\%) stated that they always had difficulties in accessing information provided by the Samosir touch application. Then 16 respondents (16\%) stated that they often had difficulties in accessing information provided by the Samosir touch application. Furthermore, 39 respondents (39\%) stated that they sometimes experienced difficulties in accessing information provided by the Samosir touch application, and 33 respondents (33\%) stated that they had never experienced difficulties in accessing information provided by the Samosir Touch application.
Based on the data above, it can be concluded that almost half of the respondents said that they sometimes had difficulty accessing the information provided by the Samosir touch application. This happens because the user feels respond time from one category menu to another a little longer, the search menu after use still displays the previous

menu.

Pattern of Utilization of the Samosir Touch Application a. Utilization of Applications as Information

The respondent's response to the use of samosir touch applications helps in tourism activities can be seen in the following table 8 :

TABLE 8. UTILIZATION OF APPLICATIONS AS INFORMATION

\begin{tabular}{|c|c|c|c|c|c|}
\hline & & Frequency & Percent & $\begin{array}{c}\text { Valid } \\
\text { Percent }\end{array}$ & $\begin{array}{l}\text { Cumulativ } \\
\text { e Percent }\end{array}$ \\
\hline \multirow[t]{5}{*}{ Valid } & Very helpful & 23 & 23.0 & 23.0 & 23.0 \\
\hline & Helpful & 47 & 47.0 & 47.0 & 70.0 \\
\hline & Less helpful & 19 & 19.0 & 19.0 & 89.0 \\
\hline & Not helpful & 11 & 11.0 & 11.0 & 100.0 \\
\hline & Total & 100 & 100.0 & 100.0 & \\
\hline
\end{tabular}

Source: Processed research data, 2017

From table 8 it can be seen that out of 100 respondents, 23 respondents $(23 \%)$ stated that the use of the Samosir touch application is very helpful in tourism activities. Then 47 respondents (47\%) stated that the use of the Samosir touch application helps in tourism activities. Furthermore, 19 respondents (19\%) stated that the use of the Samosir touch application was not very helpful in tourism activities, and 11 respondents $(11 \%)$ stated that the use of the Samosir touch application did not help in tourism activities. Based on the data above, it can be concluded that almost half of the respondents stated that the use of the Samosir touch application in tourism activities is helpful because it can be used as a source of information and tourist references.

\section{b. Treatment of Information Provided}

The respondent's response to the required information has been obtained from the Samosir touch application can be seen in the following table 9:

TABLE 9. TREATMENT OF INFORMATION PROVIDED

\begin{tabular}{|c|c|c|c|c|c|}
\hline & & Frequency & Percent & $\begin{array}{c}\text { Valid } \\
\text { Percent }\end{array}$ & $\begin{array}{l}\text { Cumulative } \\
\text { Percent }\end{array}$ \\
\hline \multirow{5}{*}{ Valid } & Save to media & 13 & 13.0 & 13.0 & 13.0 \\
\hline & Only read on monitor & 56 & 56.0 & 56.0 & 69.0 \\
\hline & $\begin{array}{l}\text { Printing the } \\
\text { information }\end{array}$ & 14 & 14.0 & 14.0 & 83.0 \\
\hline & Printing on a paper & 17 & 17.0 & 17.0 & 100.0 \\
\hline & Total & 100 & 100.0 & 100.0 & \\
\hline
\end{tabular}

Source: Processed research data, 2017 
From table 9 it can be seen that out of 100 respondents, 13 respondents $(13 \%)$ stated that the information obtained from the Samosir touch application was saved to the media. Then 56 respondents $(56 \%)$ stated that the information that had been obtained from the Samosir Touch application was only monitored. Furthermore, 14 respondents (14\%) stated that information obtained from the samosir touch application was printed, and 17 respondents $(17 \%)$ stated that the information obtained from the samosir touch application was printed on a piece of paper / notebook.

Based on the data above, it can be concluded that the majority of respondents stated that the information obtained from the Samosir Touch application is only monitored because tourists as users use the Samosir touch application with a loyal gadget accompanying them. Any information needed to stay is searched and read through the gadget monitor screen.

\section{Source of Electronic Information}

The respondent's response to the advantages possessed by the Samosir touch application compared to printed information sources / books in meeting the increasing user information needs can be seen in the following table 10:

TABLE 10. ELECTRONIC INFORMATION SOURCES

\begin{tabular}{|r|r|r|r|r|}
\hline & Frequency & Percent & $\begin{array}{c}\text { Valid } \\
\text { Percent }\end{array}$ & $\begin{array}{r}\text { Cumulative } \\
\text { Percent }\end{array}$ \\
\hline Valid $\begin{array}{c}\text { more up to date } \\
\text { information } \\
\text { Easy to access } \\
\text { More effective and } \\
\text { efficient }\end{array}$ & 19 & 19.0 & 19.0 & 19.0 \\
Doesn't have any \\
good \\
Total
\end{tabular}

Source: Processed research data, 2017

From table 10 it can be seen that out of 100 respondents, 19 respondents (19\%) stated that the advantages possessed by samosir touch applications compared to printed information sources / books in meeting the ever increasing user information needs are more up to date information. Then 36 respondents $(36 \%)$ stated that the advantages possessed by Samosir touch applications compared to printed information sources / books in meeting the increasing information needs of users were easily and quickly accessed. Furthermore, 28 respondents (28\%) stated that the advantages possessed by the Samosir touch application compared to printed information sources / books in meeting the increasing user information needs were more effective and efficient, and 17 respondents $(17 \%)$ had the advantage of Samosir touch applications. Compared to the source of printed information / books in meeting the increasing information needs of users is not having any advantages.

Based on the data above, it can be concluded that almost half of the respondents stated that the advantages possessed by the Samosir touch application compared to printed information sources / books in meeting the ever increasing user information needs are easy and fast accessed and more effective and efficient because currently technology is growing rapidly Application development in Android systems and internet networks.

\section{Accuracy and Completeness of the Samosir Touch Application}

\section{a. Accuracy of the Samosir Touch Application}

The respondent's response to the information in the Samosir touch application can be seen in table 11 below:

\begin{tabular}{|c|c|c|c|c|c|}
\hline & & Frequency & Percent & $\begin{array}{c}\text { Valid } \\
\text { Percent }\end{array}$ & $\begin{array}{c}\text { Cumulative } \\
\text { Percent }\end{array}$ \\
\hline \multirow[t]{5}{*}{ Valid } & Very accurate & 32 & 32.0 & 32.0 & 32.0 \\
\hline & Accurate & 37 & 37.0 & 37.0 & 69.0 \\
\hline & Less accurate & 19 & 19.0 & 19.0 & 88.0 \\
\hline & Not accurate & 12 & 12.0 & 12.0 & 100.0 \\
\hline & Total & 100 & 100.0 & 100.0 & \\
\hline
\end{tabular}

From table 11 it can be seen that out of 100 respondents, 32 respondents $(32 \%)$ stated that the information in the Samosir touch application was very accurate. Then 37 respondents $(37 \%)$ stated that the information in the Samosir touch application was accurate. Furthermore, 19 respondents $(19 \%)$ stated that the information on the Samosir touch application was less accurate, and 12 respondents (12\%) stated that the information contained in the Samosir touch application was inaccurate.

Based on the data above, it can be concluded that almost half of the respondents stated that the information in the Samosir touch application is accurate in fulfilling information and also as a source of information to meet the needs of users in tourism activities.

\section{b. Complete Samosir Touch Application}

The respondent's response to the completeness of the information available on the Samosir touch application can be seen in the following table 12 :

TABLE 12. COMPLETENESS OF INFORMATION

\begin{tabular}{|c|c|c|c|c|c|}
\hline & & Frequency & Percent & $\begin{array}{c}\text { Valid } \\
\text { Percent }\end{array}$ & $\begin{array}{c}\text { Cumulative } \\
\text { Percent }\end{array}$ \\
\hline \multirow[t]{5}{*}{ Valid } & Very complete & 26 & 26.0 & 26.0 & 26.0 \\
\hline & Complete & 30 & 30.0 & 30.0 & 56.0 \\
\hline & Less complete & 29 & 29.0 & 29.0 & 85.0 \\
\hline & Not complete & 15 & 15.0 & 15.0 & 100.0 \\
\hline & Total & 100 & 100.0 & 100.0 & \\
\hline
\end{tabular}

Source: Processed research data, 2017 
From table 12 it can be seen that out of 100 respondents, 26 respondents $(26 \%)$ stated that the completeness of the information contained in the samosir touch application was very complete. Then 30 respondents $(30 \%)$ stated that the complete information contained in the Samosir touch application was complete. Furthermore, 29 respondents $(29 \%)$ stated that the complete information contained in the Samosir Touch application was incomplete, and 15 respondents $(15 \%)$ stated that the completeness of the information contained in the Samosir Touch Application was incomplete.

Based on the data above, it can be concluded that almost half of the respondents stated that the complete information contained in the Samosir touch application was complete. This is because application developers build applications based on current information needs.

\section{Samosir Touch Application Content}

a. Utilization of the Samosir Touch Application Feature The respondent's response to the categories / features that are most often used in the Samosir touch application can be seen in the following table:

TABLE 13. UTILIZATION OF APPLICATION FEATURES

\begin{tabular}{|c|c|c|c|c|c|}
\hline & & Frequency & Percent & $\begin{array}{l}\text { Valid } \\
\text { Percent }\end{array}$ & $\begin{array}{c}\text { Cumulative } \\
\text { Percent }\end{array}$ \\
\hline \multirow[t]{12}{*}{ Valid } & News & 7 & 7.0 & 7.0 & 7.0 \\
\hline & Promo & 5 & 5.0 & 5.0 & 12.0 \\
\hline & Destination & 9 & 9.0 & 9.0 & 21.0 \\
\hline & Event & 14 & 14.0 & 14.0 & 35.0 \\
\hline & Facilities & 18 & 18.0 & 18.0 & 53.0 \\
\hline & Food \& drink & 10 & 10.0 & 10.0 & 63.0 \\
\hline & $\begin{array}{c}\text { Culture \& } \\
\text { nature }\end{array}$ & 8 & 8.0 & 8.0 & 71.0 \\
\hline & Geocities & 4 & 4.0 & 4.0 & 75.0 \\
\hline & Forum tourism & 7 & 7.0 & 7.0 & 82.0 \\
\hline & $\begin{array}{l}\text { Amazing } \\
\text { samosir }\end{array}$ & 14 & 14.0 & 14.0 & 96.0 \\
\hline & Info travel & 4 & 4.0 & 4.0 & 100.0 \\
\hline & Total & 100 & 100.0 & 100.0 & \\
\hline
\end{tabular}

Source: Processed research data, 2017

From table 13 it can be seen that out of 100 respondents, 7 respondents $(7 \%)$ stated that the categories / features most often used in samosir touch applications are news. Then 5 respondents $(5 \%)$ stated that the categories / features most often used in the Samosir touch application are promos. Furthermore, 9 respondents $(9 \%)$ stated that the categories / features most often used in the Samosir Touch application were destination, and 14 respondents (14\%) stated that the categories / features most frequently used in the Samosir Touch application were events, 18 respondents (18\%) stated that the categories that are most often used in Samosir touch applications are facilities, 10 respondents $(10 \%)$ stated that the categories / features most often used in samosir touch applications are food \& drink,
8 respondents $(8 \%)$ stated the categories / features that are most often used in the Samosir touch application is culture $\&$ nature, 4 respondents (4\%) stated that the category most frequently used in Samosir Touch application is Geocities, 7 respondents $(7 \%)$ stated that the categories / features that are most often used in Samosir touch applications are tourism forums, 14 respondents (14\%) stated that the categories / features that are most often used in samosir touch applications are amazing mosir, 4 respondents $(4 \%)$ stated that the category / feature most often used in the Samosir touch application is travel info.

Based on the data above it can be concluded that a small percentage of respondents stated that the categories that are often used in samosir touch applications are all categories, but among these categories that are most often used are facilities categories that contain information such as hotels, restaurants, souvenirs, transportation and so on needed by tourists when in Samosir, then the event category which contains information on events such as culture and art that have been and will be held in Samosir, then the amazing samosir category which contains photos that have been uploaded by users where users can like and comment on photos there is.

\section{b. Content Features Facilities The Samosir Touch Application}

The respondent's responses to the Samosir touch application content facilities that are most often used for tourism activities can be seen in table 14 below:

TABLE 14. CONTENT MENU / FACILITIES FACILITIES

\begin{tabular}{|c|c|c|c|c|c|}
\hline & & Frequency & Percent & $\begin{array}{c}\text { Valid } \\
\text { Percent }\end{array}$ & $\begin{array}{c}\text { Cumulative } \\
\text { Percent }\end{array}$ \\
\hline \multirow{18}{*}{ Valid } & Band & 3 & 3.0 & 3.0 & 3.0 \\
\hline & Bank & 2 & 2.0 & 2.0 & 5.0 \\
\hline & Bar/ pub & 5 & 5.0 & 5.0 & 10.0 \\
\hline & Café & 8 & 8.0 & 8.0 & 18.0 \\
\hline & Homestay & 11 & 11.0 & 11.0 & 29.0 \\
\hline & Hotel & 14 & 14.0 & 14.0 & 43.0 \\
\hline & Kantor polisi & 1 & 1.0 & 1.0 & 44.0 \\
\hline & Karaoke & 3 & 3.0 & 3.0 & 47.0 \\
\hline & $\begin{array}{l}\text { Layanan } \\
\text { kesehatan }\end{array}$ & 4 & 4.0 & 4.0 & 51.0 \\
\hline & Money changer & 3 & 3.0 & 3.0 & 54.0 \\
\hline & Pelabuhan & 2 & 2.0 & 2.0 & 56.0 \\
\hline & Restoran & 9 & 9.0 & 9.0 & 65.0 \\
\hline & Rumah ibadah & 2 & 2.0 & 2.0 & 67.0 \\
\hline & Sanggar seni & 7 & 7.0 & 7.0 & 74.0 \\
\hline & Souvenir & 10 & 10.0 & 10.0 & 84.0 \\
\hline & Taksi \& rental & 9 & 9.0 & 9.0 & 93.0 \\
\hline & $\begin{array}{l}\text { Transportasi } \\
\text { umum }\end{array}$ & 7 & 7.0 & 7.0 & 100.0 \\
\hline & Total & 100 & 100.0 & 100.0 & \\
\hline
\end{tabular}


From table 14 it can be seen that out of 100 respondents, 1 respondent $(1 \%)$ stated that the samosir touch application content facilities most often used for tourism activities were police stations, then each of the 2 respondents $(2 \%)$ stated that touch application content facilities samosir which is most often used for tourism activities is banks, ports, houses of worship, then each 3 respondents $(3 \%)$ stated that the samosir touch application content facilities that are most often used for tourism activities are bands, karaoke, money changers, and 4 Respondents (4\%) stated that Samosir Touch Application Content Facilities most often used for tourism activities were health services, 5 respondents $(5 \%)$ stated that Samosir Touch Application Content Facilities most frequently used for tourism activities were bars / pubs, 7 each Respondents (7\%) stated that Samosir touch application content facilities were the most frequently used for tourism activities are art studios and public transportation, 8 respondents $(8 \%)$ stated that the Samosir touch application content facilities that are most often used for tourism activities are cafes, each of which 9 respondents (9\%) stated that Samosir touch application content facilities are the most often used for tourism activities are restaurants and taxis \& rentals, 10 respondents $(10 \%)$ stated that touch samosir application content facilities that are most often used for tourism activities are souvenirs, 11 respondents $(11 \%)$ stated that samosir touch application content facilities are most often used for tourism activities is homestay, 14 respondents (14\%) stated that Samosir touch application content facilities most often used for tourism activities are hotels.

Based on the data above it can be concluded that a small proportion of respondents stated that Samosir touch application content facilities that are often used for tourism activities are all but the most frequently used are among others hotels, homestays, souvenirs, restaurants, taxis \& rentals.

\section{CONCLUSION}

The conclusions of this research are :

1. The majority of users $(62 \%)$ have used the Samosir Touch application by spending more than one hour each time searching for information.

2. Users most often use content from the categories / features that exist in the Samosir Touch application are facilities. It shows that the information facility is the most sought after by users because it contains information such as hotels, homestays, souvenirs, restaurants, taxis \& rentals and information that helps users during the trip in Samosir.

3. The majority of respondents $(75 \%)$ have a lot of samosir contact information through print / electronic media because there are roles in this matter.

4. From the results of the respondents' answers to all questions that can be cited that the information in the Samosir touch application has been well utilized by users, namely tourists in the Samosir area.

5. The application of Touch Samosir currently is not available in the PlayStore anymore, but it was replaced by Tobasmile in October 2018. The function of both application is similar, mainly to inform the accessibility and attraction of Toba Lake.

Based on the conclusions that have been obtained from the results of this study, the researchers suggest several suggestions including the following:

1. The existence of the Samosir touch application is important as a tourism information service in Samosir. However, the utilization of the existing Samosir touch application is not fully utilized, this is evident from many tourists who still do not know of the features that provide tourism information in Samosir, namely "Samosir touch". In this case, a maximum promotion is needed so that this application can be utilized again.

2. Samosir touch application must continue to increase the amount of content for existing information and is more up to date, so users are not disappointed when searching.

3. The samosir touch application design such as the header image must be more adjusted to the resolution so that the display is more attractive, and the response time of the menu changes faster so that the user feels access speed.

4. We recommend that the Samosir Touch application be used on an operating system other than Android and use the features with the English version.

\section{REFERENCES}

Arikunto, Suharsimi. (2002). Prosedur Penelitian : Suatu Pendekatan Praktek. Jakarta : Rineka Cipta.

Azwan, Saifudin. (2004). Metode Penelitian. Yogyakarta : Pustaka Pelajar.

Gamal, Suwantoro. (2004). Dasar-Dasar Pariwisata. Yogyakarta : Andi.

Hamid, E. A. C. (1996). Dasar-Dasar Pengetahuan Pariwisata. Jakarta : Yayasan Bhakti Membangun,

Heriawan, Rusman. (2004). Peranan dan Dampak Pariwisata Pada Perekonomian Indonesia : Suatu Pendekatan Model I-O dan SAM. Disertasi. Bogor : Doktoral Institut Pertanian Bogor.

Kuncoro, Mudrajad. (2003). Metode Riset untuk Bisnis dan Ekonomi. Jakarta : Erlangga.

Marpaung, Happy. (2000). Pengetahuan Kepariwisataan. Bandung : Alfabeta.

Nazir, Moh. (2003). Metode penelitian. Jakarta : Ghalia Indonesia.

Nawawi, Hadari. (2001). Metode Penelitian Bidang Sosial. Yogyakarta: Gajah Mada University Press

Nugroho, Eko. (2008). Sistem Informasi Manajemen. Yogyakarta : Andi. Sugiyono. (2006). Metode Penelitian Bisnis. Bandung : Alfabeta. Supardi, A. (1979). Statistik. Bandung : Fakultas Tarbiyah IAIN Sunan Gunung Jati. 
Supriyanto, Wahyu. (2008). Teknologi Informasi Perpustakaan : Strategi Perancangan Perpustakaan Perpustakaan Digital. Yogyakarta : Kanisius.

Suwantoro, G. (1997). Dasar-Dasar Pariwisata. Yogyakarta : Andi.
Tharom, Tabratas. (2002). Mengenal Teknologi Informasi. Jakarta : Gramedia.

Wardiyanta. (2006). Metode Penelitian Pariwisata. Yogyakarta : Andi. Yoeti, Oka A. (1996). Pengantar Ilmu Pariwisata. Bandung : Angkasa. 